\title{
Bibliography of Secondary Works
}

Achinstein, Sharon. "Plagues and Publication: Ballads and the Representation of Disease in the English Renaissance." Criticism, 34.1 (1992), pp. 27-49.

Amabile, Luigi. Fra Tommaso Campanella, la sua congiura, $i$ suoi processi e la sua pazzia. 2 vols. Naples: Morano, 1882.

Aries, Philippe, and Duby, Georges, eds. A History Of Private Life. 5 vols. Cambridge, mA: Harvard University Press, 1987-91.

Austin, J.L. How To Do Things with Words. 2nd ed. Oxford: Oxford University Press, 1975.

Bailey, Joanne. “'A Very Sensible Man': Imagining Fatherhood in England c.1750-1830.” History, 95 (2010), pp. 267-292.

Barker, Hannah, and Chalus, Elaine, eds. Gender in Eighteenth-Century England: Roles, Representations and Responsibilities. London: Longman, 1997.

Barnard, John, and McKenzie, D.F., eds. The Cambridge History of the Book in Britain: Volume IV1557-1695. Cambridge: Cambridge University Press, 2002.

Baron, Sabrina, and Dooley, Brendan, eds. The Politics of Information in Early Modern Europe. London: Routledge, 2001.

Barroll, Leeds. Politics, Plague, and Shakespeare's Theater: The Stuart Years. Ithaca and London: Cornell University Press, 1991.

Barry, Jonathan, and Brooks, Christopher. The Middling Sort of People: Culture, Society and Politics in England, 1550-1800. Basingstoke: Palgrave Macmillan, 1994.

Behringer, Wolfgang. Im Zeichen des Merkur: Reichspost und Kommunikationsrevolution in der Frühen Zeuzeit. Göttingen: Vanderhoeck and Ruprecht, 2003.

_ . "Communications Revolutions: A Historiographical Concept." German History, 24 (2006), pp. 333-375.

Bellany, Alastair. “'A Poem upon the Archbishop's hearse': Puritanism, Libel and Sedition after the Hampton Court Conference." Journal of British Studies, 34 (1995), pp. 285-310.

- The Politics of Court Scandal in Early Modern England: News Culture and the Overbury Affair, 1603-1660. Cambridge: Cambridge University Press, 2002.

Bertolotti, Antonio. Le pregioni di Roma nei secoli XVI, XVII e XVIII. Rome: Tipografia delle Mantellate, 1890.

Bethencourt, Francisco, and Egmond, Florike, eds. Correspondence and Cultural Exchange in Europe, 1400-1700. Cambridge: Cambridge University Press, 2007.

Black, Jeremy. The English Press in the Eighteenth Century. London: Croom Helm, 1987. Black, Robert, ed. Renaissance Thought: A Reader. London: Routledge, 2001.

Bogel, Else, and Blühm, Elger. Die deutschen Zeitungen des 17. Jahrhunderts: ein Bestandverzeichnis mit historischen und bibliographiscen Angaben. Bremen: Schünemann Universitätsverlag, 1971-85. 
Bogucka, Maria. Baltic Commerce and Urban Society 1500-1700: Gdansk/Danzig and Its Polish Context. Aldershot: Ashgate, 2003.

Booth, Mark W. The Experience of Songs. New Haven and London: Yale University Press, 1981.

Botelho, Keith M. Renaissance Earwitnesses: Rumor and Early Modern Masculinity. New York: Palgrave Macmillan, 2009.

Bowers, Rick. Radical Comedy in Early Modern England: Contexts, Cultures, Performances. Aldershot and Burlington, vT: Ashgate, 2008.

Boys, Jayne E.E. London's News Press and the Thirty Years War. Woodbridge: The Boydell Press, 2011.

Braun, Theodore E.D., and Radner, John B., eds. The Lisbon Earthquake of 1755: Representations and Reactions. Oxford: Voltaire Foundation, 2005.

Briggs, Julia. "Marlowe's Massacre at Paris: A Reconsideration." The Review of English Studies, 34, 135 (1983), pp. 237-278.

Bristol, Michael D., and Marotti, Arthur F., eds. Print, Manuscript, and Performance: The Changing Relations of the Media in Early Modern England. Columbus: Ohio State University Press, 2000.

Broersma, Marcel. Beschaafde vooruitgang: De wereld van de Leeuwarder Courant 1752-2002. Leeuwarden: Friese Pers Boekerij, 2002.

Brown, Louise Fargo. Political Activities of the Baptists and Fifth Monarchy Men during the Interregnum. Washington, D.c.: American Historical Association, 1913.

Brown, Richard K., ed. Knowledge, Education and Cultural Change. London: Tavistock, 1973.

Brown, Sarah Annes. The Metamorphosis of Ovid: From Chaucer to Ted Hughes. New York: St. Martin's Press, 1999.

Browning, Andrew. Thomas Osborne, Earl of Danby and Duke of Leeds, 1632-1712. 3 vols. Glasgow: Jackson Son \& Co., 1944-51.

Brownlees, Nicholas. Corantos and Newsbooks: Language and Discourse in the First English Newspapers (1620-1641). Pisa: Edizioni ETs, 1999.

— ed. News Discourse in Early Modern Britain. Bern: Peter Lang, 2006.

—_. The Language of Periodical News in Seventeenth-Century England. Newcastle upon Tyne: Cambridge Scholars Publishing, 2011.

Buisman, Jan Willem "Het bevend Nederland: De Republiek en de aardbeving van Lissabon 1755-1756." Tijdschrift voor Geschiedenis, 92 (1979), pp. 33-235.

Burnette, Joyce. Gender, Work and Wages in Industrial Revolution Britain. Cambridge: Cambridge University Press, 2008.

Butler, Marilyn. Romantics, Rebels and Reactionaries. New York and Oxford: Oxford University Press, 1982.

Cametti, Alberto. "La torre di Nona e la contrada circostante dal medio evo al secolo XVIII." Archivio della società romana di storia patria, 29 (1916), pp. 411-466. 
Carretta, Vincent. The Snarling Muse: Verbal and Visual Political Satire from Pope to Churchill. Philadelphia: University of Pennsylvania Press, 1983.

Chartier, Roger, ed. A History Of Private Life III: Passions of the Renaissance. Cambridge, MA: Harvard University Press, 1989.

Clark, Sandra. The Elizabethan Pamphleteers: Popular Moralistic Pamphlets 1580-1640. Rutherford, NJ: Fairleigh Dickinson University Press, 1983.

- Women and Crime in the Street Literature of Early Modern England. Basingstoke: Palgrave, 2003.

Clarke, Howard, ed. Vergil's Aeneid and Fourth ('Messianic') Eclogue in the Dryden Translation. University Park, PA, and London: Pennsylvania State University Press, 1989.

Clegg, Susan. Press Censorship in Jacobean England. Cambridge: Cambridge University Press, 2001.

Connery, Brian A., and Combe, Kirk, eds. Theorizing Satire. New York: St Martin's Press, 1995.

Couvée, Dirk H. “The Administration of the 'Oprechte Haarlemse Courant' 1738-1742." Gazette: International Journal of the Science of the Press etc., 4 (1958), pp. 91-110.

Crawford, Julie. Marvelous Protestantism: Monstrous Births in Post-Reformation England. Baltimore and London: The Johns Hopkins University Press, 2005.

Cressy, David. Travesties and Transgressions in Tudor and Stuart England: Tales of Discord and Dissension. Oxford: Oxford University Press, 2000.

Dahl, Folke. Dutch Corantos 1618-1650: A Bibliography. The Hague: Koninklijke Bibliotheek, 1946.

—. "Amsterdam: Cradle of the English Newspapers." The Library, 5th series, 4 (1949), pp. 166-178.

- A Bibliography of English Corantos and Periodical Newsboosk, 1620-1642. London: Bibliographical Society, 1952.

Dahl, Folke, with Petibon, Fanny, and Boulet, Marguerite. Les Debuts de la Presse Française: Nouveaux Aperçus. Göteburg and Paris: Wettergren and Kerber, 1951.

Daybell, James, and Hinds, Peter, eds. Material Readings of Early Modern Culture: Texts and Social Practices, 1580-1730. Basingstoke: Palgrave Macmillan, 2010.

De Groot Jerome. Royalist Identities. Basingstoke: Palgrave Macmillan, 2004.

De Vivo, Filippo. Information and Communication in Venice: Rethinking Early Modern Politics. Cambridge: Cambridge University Press, 2007.

Del Re Niccolò. Il maresciallo di Santa Romana Chiesa. Rome: Istituto di studi romani, 1962.

—_. "Il governatore di Borgo." Studi Romani, 11 (1963), pp. 13-29.

Dionne, Craig, and Mentz, Steve, eds. Rogues and Early Modern English Culture. Ann Arbor: University of Michigan Press, 2004. 
Djabri, Susan C. “The 'Dragon' of St. Leonard's Forest.” Horsham Heritage, 14 (Spring 2006), pp. 3-16.

Dolan, Frances. True Relations: Reading, Literature, and Evidence in SeventeenthCentury England. Philadelphia: University of Pennsylvania Press, 2013.

Donald, Diana. The Age of Caricature: Satirical Prints in the Reign of George III. New Haven: Yale University Press, 1996.

D’Onofrio, Cesare. “Gli 'Avvisi' di Roma dal 1554 al 1605.” Studi Romani, 10 (1962), pp. 529-548.

Dooley, Brendan. "De bonne main: les pourvoyeurs de nouvelles à Rome au XVII siècle." Annales: Histoire, Sciences sociales, 6 (1999), pp. 1317-1344.

- The Social History of Skepticism: Experience and Doubt in Early Modern Culture. Baltimore: Johns Hopkins University Press, 1999.

- Morandi's Last Prophecy and the End of Renaissance Politics. Princeton: Princeton University Press, 2002.

— ed. The Dissemination of News and the Emergence of Contemporaneity in Early Modern Europe. Farnham and Burlington, vT: Ashgate, 2010.

Dutton, Richard. Licensing, Censorship and Authorship in Early Modern England. Buggeswords. Basingstoke: Palgrave, 2000.

Earle, Peter. "The Female Labour Market in London in the Late Seventeenth and Early Eighteenth Centuries." The Economic Review, New Series, 42 (1989), pp. 328-353.

—. The Making of the English Middle Class: Business, Society and Family Life in London 1660-1730. Berkeley: Methuen and University of California Press, 1989.

Elliott, Robert. The Power of Satire. Princeton: Princeton University Press, 1960.

Espejo, Carmen. "European Communication Networks in the Early Modern Age." Media History, 17. 2 (2011), pp. 189-202.

Fairclough, Norman. Media Discourse. London: Edward Arnold, 1995.

Faller, Lincoln B. Turned to Account: The Forms and Functions of Criminal Biography in Late Seventeenth- and Early Eighteenth-Century England. Cambridge: Cambridge University Press, 1987.

Feather, John. A History of British Publishing. London and New York: Routledge, 2005.

Ferdinand, Christine Y. Benjamin Collins and the Provincial Newspaper Trade in the Eighteenth Century. Oxford: Oxford University Press, 1997.

Fletcher, Anthony. Gender, Sex and Subordination in England 1500-1800. New Haven and London: Yale University Press, 1995.

Foucault, Michel. Discipline and Punish: The Birth of the Prison. New York: Vintage Books, 1995.

Fox, Adam. "Rumor, News, and Popular Public Opinion in Elizabethan and Early Stuart England.” The Historical Journal, 40 (1997), pp. 592-620.

- Oral and Literate Culture in England, 1500-1700. Oxford: Oxford University Press, 2000 . 
Fox, Adam, and Woolf, Daniel, eds. The Spoken Word: Oral Culture in Britain, 1500-1850. Manchester: Manchester University Press, 2002.

Fragnito, Gigliola, ed. Church, Censorship and Culture in Early Modern Italy. Cambridge: Cambridge University Press, 2001.

Frank, Joseph. The Beginnings of the English Newspaper; 1620-1660. Cambridge: Harvard University Press, 1961.

Frearson, Michael. "London Corantos in the 1620s." Studies in Newspaper and Periodical History, 1 (1993), pp. 3-17.

Freeman, Arthur, and Freeman, Janet Ing.John Payne Collier: Scholarship and Forgery in the Nineteenth Century. New Haven: Yale University Press, 2004.

French, Henry, and Barry, Jonathan, eds. Identity and Agency in England, 1500-1800. Palgrave, 2004.

Frenk, Joachim, and Steveker, Lena, eds. Proceedings: Anglistentag 2010 Saarbrücken. Trier: WvT, 2010.

Friedman, Jerome. Miracles and the Pulp Press During the English Revolution: The Battle of the Frogs and Fairford's Flies. London: UCL Press, 1993.

Frost, Robert. The Northern Wars: War, State and Society in Northeastern Europe, 1558-1721. Harlow: Longman, 2000.

Frye, Northrop. Anatomy of Criticism: Four Essays. Princeton: Princeton University Press, 1957.

Fumerton, Patricia. "Not Home: Alehouses, Ballads, and the Vagrant Husband in Early Modern England." Journal of Medieval and Early Modern Studies, 22.3 (2002), pp. 493-518.

Gaskill, Malcolm. "Reporting Murder Fiction in the Archives in Early Modern England." Social History, 23 (1998), pp. 1-30.

- Crime and Mentalities in Early Modern England. Cambridge: Cambridge University Press, 2000.

Gatrell, Vic. City of Laughter: Sex and Satire in Eighteenth-Century London. London: Atlantic, 2006.

Georgi, Matthias. Heuschrecken, Erdbeben und Komenten: Naturkatastrophen und Naturwissenschaft in der englischen Öffentlichkeit des 18. Jahrhunderts. Munich: August Dreesbach Verlag, 2009.

Gilman, Ernest B. Plague Writing in Early Modern England. Chicago: University of Chicago Press, 2009.

Godfrey, Richard T., and Hallett, Mark. James Gillray: The Art of Caricature. London: Tate, 2001.

Goldie, Mark, Harris, Tim, and Seaward, Paul, eds. The Politics of Religion in Restoration England. Oxford: Oxford University Press, 1990.

Gowing, Laura. Common Bodies: Women, Touch and Power in Seventeenth Century England. New Haven and London: Yale University Press, 2003. 
Green, Ian. Print and Protestantism in Early Modern England. Oxford: Oxford University Press, 2000.

Greenberg, Marissa. "Signs of the Crimes: Topography, Murder, and Early Modern Domestic Tragedy." Genre, 40. 1 (2007), pp. 1-29.

Griffiths, Anthony. The Print in Stuart Britain. London: British Museum Press, 1998.

Habermas, Jürgen. The Structural Transformation of the Public Sphere: An Inquiry into a Category of Bourgeois Society. Cambridge: Polity Press, 1989.

Halasz, Alexandra. The Marketplace of Print: Pamphlets and the Public Sphere in Early Modern England. Cambridge: Cambridge University Press, 1997.

Hallet, Mark. The Spectacle of Difference: Graphic Satire in the Age of Hogarth. New Haven: Yale University Press, 1999.

Harms, Roeland, Raymond, Joad, and Salman, Jeroen, eds. Not Dead Things - The Dissemination of Popular Print in England and Wales, Italy, and the Low Countries, 1500-1820. Leiden and Boston: Brill, 2013.

Harris, Tim. London Crowds in the Reign of Charles II: Propaganda and Politics from the Restoration until the Exclusion Crisis. Cambridge: Cambridge University Press, 1987.

— ed. The Politics of the Excluded, c. 1500-1800. New York: Palgrave, 2001.

- Restoration: Charles II and his Kingdoms 1660-1685. London: E. Arnold, 2006.

Harte, Jeremy. “The Sussex Serpent.” Folklore, 105 (1994), pp. 103-104.

Healy, Margaret. Fictions of Disease in Early Modern England: Bodies, Plagues and Politics. Basingstoke: Palgrave. 2001.

Herrup, Cynthia B. The Common Peace: Participation and the Criminal Law in Seventeenth-Century England. Cambridge: Cambridge University Press, 1987.

Hinds, Peter. The Horrid Popish Plot: Roger L'Estrange and the Circulation of Political Discourse in Late Seventeenth-Century London. Oxford: Oxford University Press, 2010.

Hitchcock, Tim, and Cohen, Michèle, eds. English Masculinities 1660-1800. London and New York: Longman, 1999.

Ho, Elaine Y.L. “The Rhetoric of the 'I'-Witness in Fulke Greville's The Life of Sir Philip Sidney." Literature and History, 2nd series, 2, 1 (Spring 1991), pp. 17-26.

Hoitsema, Copius. De drukkersgeslachten Sipkes-Hoitsema en de Groninger Courant. Groningen: Verenigde Drukkerijen Hoitsema, 1953.

Horodowich, Elizabeth. Language and Statecraft in Early Modern Venice. Cambridge: Cambridge University Press, 2008.

Howard-Hill, T.H. Middleton's Vulgar Pasquin: Essays on A Game at Chess. Newark: University of Delaware Press, 1995.

Hufton, Olwen H. The Prospect Before Her: A History of Women in Western Europe Volume One 1500-1800. London: Harper Collins, 1996.

Hulme, Peter. Colonial Encounters: Europe and the Native Caribbean, 1492-1797. London: Methuen, 1986. 
Hunt, John. “The Conclave from the 'Outside In': Rumor, Speculation, and Disorder in Rome during Early Modern Papal Elections." Journal of Early Modern History, 16 (2012), pp. 355-382.

Hunter, Michael, ed. Printed Images in Early Modern Britain. Aldershot: Ashgate, 2010.

Johns, Adrian. The Nature of the Book: Print and Knowledge in the Making. Chicago: University of Chicago Press, 1998.

Johnson, Gerald D. “John Busby and the Stationers' Trade, 1590-1612." The Library, 6th series, 7 (1985), pp. 1-15.

—_. "John Trundle and the Book-Trade, 1603-1626." Studies in Bibliography, 39 (1986), pp. 178-199.

Jones, Clyve, ed. Britain in the First Age of Party 1680-1750: Essays Presented to Geoffrey Holmes. London: Hambledon Press, 1987.

Jones, Malcolm. The Print in Early Modern England:An Historical Oversight. New Haven and London: Yale University Press, 2010.

Jones, Steven E. Satire and Romanticism. Basingstoke: Macmillan, 2000.

Jones-Davies, M.T., ed. Rumeurs et Nouvelles au Temps de la Renaissance. Paris: Editions Klincksieck, 1977.

Jucker, Andreas H., ed. Early Modern English News Discourse: Newspapers, Pamphlets and Scientific News Discourse. Amsterdam and Philadelphia: John Benjamins Publishing Company, 2007.

Kapferer, Jean-Noël. Rumors: Use, Interpretations, and Images. New Brunswick: Transaction Publishers, 1990.

Keller, Caren auf dem. Textual Structures in Eighteenth-century Newspaper Advertising. A Corpus-based Study of Medical Advertisements and Book Advertisements. Aachen: Shaker, 2004.

Kenyon, J.P. “The Acquittal of Sir George Wakeman.” Historical Journal, 14 (1971), pp. 693-708.

Klein, Lawrence E. "Gender and the Public/Private Distinction in the Eighteenth Century: Some Questions about Evidence and Analytic Procedure." Eighteenth-Century Studies, 29 (1995), pp. 97-109.

Knight, Jeremy, and Semmens, Jason, eds. Horsham's Dragon. Horsham: Horsham Museum Society, 2007.

Knights, Mark. Politics and Opinion in Crisis. Cambridge: Cambridge University Press, 1994.

Koopmans, Joop W., ed. News and Politics in Early Modern Europe (1500-1800). Leuven, Paris, and Dudley, MA: Peeters, 2005.

- . "Groningen en het tempo van internationaal nieuws: Een vergelijking van kranten uit de 18e eeuw, toegespitst op berichten over de aardbeving en tsunami van Lissabon (1755)." Historisch jaarboek Groningen (2011), pp. 36-51. 
Koopmans, Joop W., and Petersen, Nils Holger. Commonplace Culture in Western Europe in the Early Modern Period III: Legitimation of Authority. Leuven, Paris and Walpole, MA: Peeters, 2011.

Lake, Peter, with Questier, Michael. The Antichrist's Lewd Hat: Protestants, Papists and Players in Post-Reformation England. New Haven: Yale University Press, 2002.

Lake, Peter. "Puritanism, Arminianism and a Shropshire axe-murder." Midland History, 15 (1990), pp. 37-64.

Lake, Peter, and Pincus, Steven C.A., eds. The Politics of the Public Sphere in Early Modern England. Manchester: Manchester University Press, 2007.

Lambert, Ennis. "Anthony Nixon: Jacobean Plagarist and Hack." The Huntington Library Quarterly, 3 (1940), pp. 377-401.

Lambert, Sheila. "Coranto Printing in England: The First Newsbooks." Journal of Newspaper and Periodical History, 8 (1992), pp. 3-19.

Langer, Andrea, and Michels, Georg, eds. Metropolen Und Kulturtransfer Im 15./16. Jahrhundert.: Prag - Krakau - Danzig - Wien. Stuttgart: Franz Steiner Verlag, 2001.

Lankau, Jan. Prasa Staropolska na tle rozwoju prasy w Europie 1513-1729. Kraków: Państwowe Wydawnictwo Naukowe, 1960.

Latham, Charlotte. “Some West Sussex Superstitions Lingering in 1868." The Folklore Record, 1 (1878), pp. 1-67.

Lee, Rensselaer W. "Ut Pictura Poesis: The Humanistic Theory of Painting." Art Bulletin, 22 (1940), pp. 197-269.

Lefebvre, Georges. The Great Fear: Rural Panic in Revolutionary France. New York: Pantheon Books, 1979.

Lesser, Zachary. Renaissance Drama and the Politics of Publication: Readings in the English book Trade. Cambridge: Cambridge University Press, 2004.

Lieblein, Leonore. "The Context of Murder in English Domestic Plays, 1590-1610." Studies in English Literature, 1500-1900, 23. 2 (1983), pp. 181-196.

Limon, Jerzy. Dangerous Matter: English Drama and Politics in 1623/24. Cambridge: Cambridge University Press, 1986.

Lin, Erika T. Shakespeare and the Materiality of Performance. Basingstoke: Palgrave Macmillan, 2012.

Love, Harold. English Clandestine Satire 1660-1720. Oxford: Oxford University Press, 2004.

Lowenstein, David, and Mueller, Janel, eds. The Cambridge History of Early Modern English Literature. Cambridge: Cambridge University Press, 2002.

Manley, Lawrence. Literature and Culture in Early Modern London. Cambridge: Cambridge University Press, 1995.

Marsh, Christopher. Music and Society in Early Modern Period. Cambridge: Cambridge University Press, 2010.

Mazzola, Elizabeth, and Abate, Corrine S., eds. Privacy, Domesticity and Women in Early Modern England. Aldershot: Ashgate, 2003. 
McCullough, Peter. "Print, Publication, and Religious Politics in Caroline England." The Historical Journal, 51 (2008), pp. 285-313.

McElligott, Jason. Royalism, Print and Censorship in Revolutionary England. Woodbridge and Rochester, NY: Boydell Press, 2007.

McKerrow, R.B. "Edward Aldee as a Typical Trade Printer." The Library, 4th series, 10 (1929-30), pp. 121-162.

McLuskie, Kathleen E. Dekker and Heywood: Professional Dramatists. New York: St. Martin's Press, 1994.

McShane, Angela. "The Roasting of the Rump: Scatology and the Body Politic in Restoration England." Past and Present, 196 (2007), pp. 253-272.

—. "Subjects and Objects: Material Expressions of Love and Loyalty in SeventeenthCentury England." Journal of British Studies, 48.4 (2009), pp. 871-886.

Miller, John. Charles II. London: Wiedenfeld and Nicholson, 1981.

Moretti, Arthur F., and Bristol, Michael D. Print, Manuscript, Performance: The Changing Relations of the Media in Early Modern England. Columbus: Ohio State University Press, 2000.

Mormando, Franco, and Worcester, Thomas, eds. Piety and Plague: From Byzantium to the Baroque. Kirksville, mo: Truman State University Press, 2007.

Muggli, Mark Z. "Ben Jonson and the Business of News." Studies in English Literature, 32 (1992), pp. 323-340.

Muir, Edward, and Ruggiero, Guido, ed. Microhistory and the Lost Peoples of Europe. Baltimore: Johns Hopkins University Press, 1991.

Mulryne, J.R., and Shewring, Margaret, eds. Theatre and Government Under the Early Stuarts. Cambridge: Cambridge University Press, 1993.

Munro, Ian. "Making Publics: Secrecy and Publication in A Game at Chess." Medieval and Renaissance Drama in England, 14 (2001), pp. 207-226.

- The Figure of the Crowd in Early Modern London: The City and Its Double. New York: Palgrave Macmillan, 2005.

Murdoch, Steve, ed. Scotland and the Thirty Years' War, 1618-1648. Leiden and Boston: Brill, 2001.

Myers, Robin, and Harris, Michael, eds. Serials and Their Readers, 1620-1914. New Castle, DE: St Paul's Bibliographies, 1993.

Neill, Michael. Issues of Death: Mortality and Identity in English Renaissance Tragedy. Oxford: Clarendon Press, 1997.

Niccoli, Ottavia. Prophecy and People in Renaissance Italy. . Trans. Lydia G. Cochrane Princeton: Princeton University Press, 1990.

Nichols, J.G. The Poetry of Ben Jonson. London: Routledge, 1969.

Noci, Javier Díaz. "Dissemination of News in the Spanish Baroque." Media History, 18. 3-4 (2012): pp. 409-421.

Norman, Donald A. Learning and Memory. San Francisco: W.H. Freeman, 1982. 
Nussdorfer, Laurie. "The Vacant See: Ritual and Protest in Early Modern Rome." Sixteenth Century Journal, 18 (1987), pp. 173-189.

- Civic Politics in the Rome of Urban VIII. Princeton: Princeton University Press, 1992.

O'Callaghan, Michelle. The English Wits: Literature and Sociability in Early Modern England. Cambridge: Cambridge University Press, 2007.

Ong, Walter. Orality and Literature: The Technologizing of the Word. London and New York: Routledge, 2002.

Orlin, Lena Cowen. Locating Privacy in Tudor London. Oxford: Oxford University Press, 2007.

Overvoorde, Jacob C. Geschiedenis van het postwezen in Nederland vóór 1795, met de voornaamste verbindingen met het buitenland. Leiden: A.W. Sijthoff, 1902.

Paice, Edward. Wrath of God: The Great Lisbon Earthquake of 1755. London: Quercus, 2008.

Palmer, John, and Price, Martin, eds. Literary Theory and Structure: Essays in Honour of William K. Wimsatt. New Haven: Yale University Press, 1973.

Pantzer, Katharine F., ed. A Short-Title Catalogue of Books Printed in England, Scotland, and Ireland and of English Books Printed Abroad 1475-1640: Vol. 3. London: The Bibliographical Society, 1991.

Parmalee, Lisa Ferraro. Good Newes from Fraunce: French Anti-League Propaganda in Late Elizabethan England. Rochester, NY: University of Rochester Press, 1996.

Paul Hunter, J. Before Novels. London and New York: Norton, 1990.

Paulson, Ronald. "The Harlot's Progress and the Tradition of History Painting." Eighteenth Century Studies, 1 (1967), pp. 69-92.

Peacey, Jason. Politicians and Pamphleteers: Propaganda During the English Civil Wars and Interregnum. Aldershot: Ashgate, 2004.

Peltonen, Markku. Classical Humanism and Republicanism in English Political Thought, 1570-1640. Cambridge: Cambridge University Press, 1995.

Pettegree, Andrew. The Book in the Renaissance. New Haven: Yale University Press, 2010.

Pierce, Helen. Unseemly Pictures: Graphic Satire and Politics in Early Modern England. New Haven: Yale University Press, 2008.

Pincus, Steven C.A. “'Coffee Politicians Does Create': Coffeehouses and Restoration Political Culture." Journal of Modern History, 67 (1995), pp. 807-834.

- Protestantism and Patriotism: Ideologies and the Making of English Foreign Policy, 1650-1668. Cambridge: Cambridge University Press, 1996.

Pollock, John. The Popish Plot: A Study in the History of the Reign of Charles II. London: Duckworth \& Co., 1903.

Potter, Lois. Secret Rites and Secret Writing: Royalist Literature, 1641-1660. Cambridge: Cambridge University Press, 1989. 
Raffield, Paul. Images and Cultures of Law in Early Modern England. Cambridge: Cambridge University Press, 2004.

Randall, David. Credibility in Elizabethan and Early Stuart Military News. London: Pickering and Chatto, 2008.

Randolph, M.C. "The Medical Concept in English Renaissance Satire." Studies in Philology, 38 (1941), pp. 125-157.

—. “Thomas Drant's Definition of Satire, 1566." Notes and Queries, 180 (1941), pp. 416-418.

—. "The Structural Design of the Formal Verse Satire." Print Quarterly, 21 (1942), pp. 368-390.

Raven, James. "New Reading Histories, Print Culture and the Identification of Change: The Case of Eighteenth Century England." Social History, 23 (1998), pp. 268-287.

Raymond, Joad. Making the News: An Anthology of the Newsbooks of Revolutionary England 1641-1660. Moreton-in-Marsh: The Windrush Press, 1993.

- News, Newspapers, and Society in Early Modern Britain. London: Routledge, 2002.

- Pamphlets and Pamphleteering in Early Modern Britain. Cambridge: Cambridge University Press, 2003.

The Invention of the Newspaper. English Newsbooks 1641-1649. 2nd ed. Oxford: Oxford University Press, 2005.

ed. News Networks in Seventeenth Century Britain and Europe. London and New York: Routledge, 2007.

ed. The Oxford History of Popular Print Culture: Volume 1-Cheap Print in Britain and Ireland to 1660. Oxford: Oxford University Press, 2011.

Razovsky, Helaine. "Popular Hermeneutics: Monstrous Children in English Renaissance Broadside Ballads." Early Modern Literary Studies, 2.3 (1996), pp. 1-34.

Robertson, Ritchie. Mock Epic Poetry from Pope to Heine. Oxford: Oxford University Press, 2009.

Rodocanachi, Emmanuel. The Roman Capitol in Ancient and Modern Times. Trans. Frederick Lawton. London: William Heinemann, 1906.

—. Le château Saint-Ange. Paris: Hachette, 1909.

Rospocher, Massimo. Beyond the Public Sphere: Opinions, Publics, Spaces in Early Modern Europe. Bologna: Il Mulino, 2012.

Salamonowicz, Stanisław, ed. Mieszczaństwo Gdańskie. Gdańsk: Gdańskie Towarzystwo Naukowe, 1997.

Sawyer, Jeffrey K. Printed Poison: Pamphlet Propaganda, Faction Politics, and the Public Sphere in Early Seventeenth-Century France. Berkeley: University of California Press, 1990.

Schleck, Julia. "Fair and Balanced' News from the Continent." Prose Studies: History, Theory, Criticism, 29.3 (2007), pp. 323-335. 
Scott, James C. Domination and the Arts of Resistance: Hidden Transcripts. New Haven: Yale University Press, 1990.

Seargeant, Philip. "Discursive Diversity in the Textual Articulation of Epidemic Disease in Early Modern England." Language and Literature, 16. 4 (2007), pp. 323-344.

Searle, John R. Speech Acts: An Essay in the Philosophy of Language. Cambridge: Cambridge University Press, 1980.

Seidel, M. Satiric Inheritance: Rabelias to Sterne. Princeton: Princeton University Press, 1979.

Shapiro, Barbara J. A Culture of Fact. England, 1550-1720. Ithaca and London: Cornell University Press, 2000.

Sharpe, James. "Last Dying Speeches': Religion, Ideology and Public Execution in Seventeenth-Century England." Past and Present, 107.1 (1985), pp. 144-167.

—. Dick Turpin: The Myth of the English Highwayman. London: Profile Books, 2004.

Sharpe, Kevin. "Celebrating a Cultural Turn: Political Culture and Cultural Politics in Early Modern England.” Journal of Early Modern History, 1 (1997), pp. 344-368.

—. "Representations and Negotiations: Texts, Images and Authority in Early Modern England.” Historical Journal, 42 (1999), pp. 853-881.

- Image Wars:Promoting Kings and Commonwealths in England, 1603-1660. New Haven: Yale University Press, 2010.

Sharpe, Kevin, and Lake, Peter, eds. Culture and Politics in Early Modern England. Basingstoke: Macmillan, 1994.

Shoemaker, Robert B. Gender in English Society, 1650-1850: The Emergence of Separate Spheres? London and New York: Longman, 1998.

Shrady, Nicholas. The Last Day: Wrath, Ruin, and Reason in the Great Lisbon Earthquake of 1755. New York: Viking, 2008.

Signorotto, Gianvitorio, and Visceglia, Maria Antonietta, eds. Court and Politics in Papal Rome. Cambridge: Cambridge University Press, 2002.

Skowron, Ryszard, ed. Polska wobec wielkich konfliktów w Europie nowożytnej. Z dziejów dyplomacji i stosunków międzynarodowych. Kraków: Societas Vistulana, 2009.

Slack, Paul. The Impact of Plague in Tudor and Stuart England. London: Routledge and Kegan Paul, 1985.

Slauter, Will. "Le paragraphe mobile: circulation et transformation des informations dans le monde atlantique du XVIIIe siècle.” Annales: Histoire, Sciences Sociales, 67 (2012), pp. 363-389.

Smith, Bruce. The Acoustic World of Early Modern England: Attending to the O-Factor. Chicago and London: University of Chicago, 1999.

Smith, Helen, and Wilson, Louise, eds. Renaissance Paratexts. Cambridge: Cambridge University Press, 2011.

Smith, Nigel. Literature and Revolution in England, 1640-1660. New Haven: Yale University Press, 1994. 
Sommerville, C. John. The News Revolution in England. Oxford: Oxford University Press, 1996.

Spinks, Jennifer. Monstrous Births and Visual Culture in Sixteenth-century Germany. London: Chatto and Pickering, 2009.

Spraggs, Gillian. Outlaws and Highwaymen: The Cult of the Robber in England from the Middle Ages to the Nineteenth Century. London: Pimlico, 2001.

Staub, Susan C., ed. 'Nature's Cruel Stepdames': Murderous Women in the Street Literature of Seventeenth Century England. Pittsburgh: Duquesne University Press, 2005.

Strong, Roy. London: A Social History. Cambridge, MA: Harvard University Press, 2001.

Suarez, Michael F., and Woudhuysen, H.R., eds. The Oxford Companion to the Book. 2 vols. Oxford: Oxford University Press, 2010.

Sweet, Rosemary. The English Town 1680-1840: Government, Society and Culture. London: Longman, 1999.

Tammeling, Bart P. De krant bekeken: De geschiedenis van de dagbladen in Groningen en Drenthe. Groningen: Nieuwsblad van het Noorden, 1988.

Test, George A. Satire: Spirit and Art. Tampa: University of South Florida Press, 1991.

Thomas, Keith. Religion and the Decline of Magic. New York: Scribner's, 1971.

Thomas, Max W. “Kemp's Nine Daies Wonder: Dancing Carnival into the Market”. PMLA, 107 (1992), pp. 511-523.

Todorov, Tzvetan, ed. French Literary Theory Today: A Reader. Trans. R. Carter. Cambridge: Cambridge University Press, 1982.

Totaro, Rebecca, ed. The Plague in Print: Essential Elizabethan Sources, 1558-1603. Pittsburgh: Duquesne University Press, 2010.

Totaro, Rebecca, and Gilman, Ernest B., eds. Representing the Plague in Early Modern England. New York and London: Routledge, 2011.

Tricomi, Albert H. Anticourt Drama in England 1603-1624. Charlottesville: University Press of Virginia, 1989.

Tsakona, Villy, and Popa, Diana Elena, eds. Studies in Political Humour. Amsterdam and Philadelphia: John Benjamin's Publication Co., 2011.

Twyning, John. London Dispossessed: Literature and Social Space in the Early Modern City. London: Macmillan, 1998.

Underdown, David. Royalist Conspiracy in England 1649-1660. New Haven: Yale University Press, 1960.

- A Freeborn People: Politics and the Nation in Seventeenth-Century England. Oxford: Clarendon Press, 1996.

Vickery, Amanda. Behind Closed Doors: At Home in Georgian England. New Haven and London: Yale University Press, 2010.

Von Pastor Ludwig. The History of the Popes from the Close of the Middle Ages. 40 vols. London: Kegan Paul, 1891-1953. 
Voss, Paul J. Elizabethan News Pamphlets: Shakespeare, Spenser, Marlowe, and the Birth of British Journalism. Pittsburgh: Duquesne University Press, 2001.

Waage, Frederick O. Thomas Dekker's Pamphlets, 1603-1609, and Jacobean Popular Literature. 2 vols. Salzburg: Universität Salzburg, 1977.

Walker, Daniel P. Spiritual and Demonic Magic from Ficino to Campanella. University Park, PA: Pennsylvania State University, 2000.

Walsham, Alexandra. Providence in Early Modern England. Oxford: Oxford University Press, 1999.

Watt, Tessa. Cheap Print and Popular Piety, 1550-1640. Cambridge: Cambridge University Press, 1991.

Weber, Johannes. "Strassburg, 1605: The Origins of the Newspaper in Europe." German History, 24.3 (2006), pp. 387-412.

Weinbrot, Howard D. "The Pattern of Formal Verse Satire in the Restoration and the Eighteenth Century." PMLA, 80 (1965), pp. 394-401.

—. "History, Horace and Augustus Caesar: Some Implications for EighteenthCentury Satire." Eighteenth-Century Studies, 7 (1974), pp. 391-414.

—. Eighteenth-Century Satire. Cambridge: Cambridge University Press, 1988.

Whitrow, G.J. The Natural Philosophy of Time. Oxford: Oxford University Press, 1980.

Wilson, Eric. "Plagues, Fairs, and Street Cries: Sounding Our Society and Space in Early Modern London." Modern Language Studies, 25.3 (Summer 1995), pp. 1-42.

Wittkower, Rudolf. "Marvels of the East: A Study in the History of Monsters." Journal of the Warburg and Courtould Institutes, 5 (1942), pp. 159-197.

Wood, Marcus. Radical Satire and Print Culture 1790-1822. Oxford: Oxford University Press, 1994.

Woodbridge, Linda. "Jest Books, the Literature of Roguery, and the Vagrant Poor in Renaissance England." English Literary Renaissance, 33 (2003), pp. 201-210.

Würzbach, Natascha. The Rise of the English Street Ballad, 1550-1650. Trans. Gayna Wallis. Cambridge: Cambridge University Press, 1990.

Zaret, David. Origins of Democratic Culture - Printing, Petitions. and the Public Sphere in Early-Modern England. Princeton: Princeton University Press, 1999. 